\title{
The Mysteries of Food: Reading Select Detective Fiction by Kalpana Swaminathan and Madhumita Bhattacharyya
}

\author{
Somjeeta Pandey ${ }^{1} \&$ Somdatta Bhattacharya ${ }^{2}$ \\ ${ }^{1}$ Assistant Professor of English, Gobardanga Hindu College, E-mail: \\ somjeetao72@gmail.com,https://orcid.org/oooo-ooo1-8107-9686 \\ ${ }^{2}$ Assistant Professor, Department of Humanities and Social Sciences, IIT Kharagpur, E- \\ mail: somdatta@hss.iitkgp.ac.in, https://orcid.org/oooo-ooo1-8332-7989
}

\begin{abstract}
Food studies, a new addition to the family of humanities, has experienced a rapid rise in the last twenty years and a number of scholars have devoted their time and energy in studying food culture as well as the patterns of eating (Albala, 2013). Food writing has slowly spread its branches into all literary genres including into crime fiction. In more recent crime mysteries, the main plot is supplemented by authentic recipes and descriptions of food and cooking and "gumshoes not only track killers" but also "grill sherryflavoured tuna" or "bake" chocolate cookies (Carvajal, 1997). The sub-genre of crime fiction that brings together food and crime, has been termed as 'culinary mystery' and with the more recent academic interest in food in literature, it has received the critical attention it deserves. The present paper will analyze the role of food in the Reema Ray mysteries of Madhumita Bhattacharyya, The Masala Murder (2012) and Dead in a Mumbai Minute (2014) and the Lalli mysteries of Kalpana Swaminathan, The Secret Gardener (2013) and Page 3 Murders (2006). While for Lalli and her niece Sita, food becomes a luxury, an indulgenceafter a hard day's grim investigative work; for Reema, baking is her sleuthing tool and stands for her intelligence and autonomy. This paper will thus argue how these novels, with female sleuths who use food/cooking as tools of detection, pose a challenge to the patriarchal roles assigned to women as caregivers and providers of nutrition, and attempt to show how "food mysteries are ultimately about female independence and sustaining the self" (Kalikoff, 2006, p. 75). In doing this, it will alsofocus on how women bridge the gap between the public and private spheres.
\end{abstract}

Keywords: detective fiction, food studies, crime fiction, Indian English women authors

“Three thousand years of Indian gluttony, for godssake! That's roughly 3,285,00o square miles of food. . .

Tarok smiled.

'Three thousand years of Indian cuisine cannot be talked about. But it can be savoured. Bon appétit!"' (The

Page 3 Murders, 127)

Food studies, has often been discussed within disciplinary domains of History and Sociology, and as Ken Albala says “...a critical mass of professional academics have devoted a significant proportion of their energy to questions of food supply, patterns of eating, in fact, all aspects of food culture or foodways" (p.1).The connections between food and literature have been explored more recently, and food writing has slowly spread its branches into all literary genres including into crime fictionas well. That is why, in the recent past, we have crime mysteries, where the main

(C) AesthetixMS 2020. This Open Access article is published under a Creative Commons Attribution Non-Commercial 4.o International License (http://creativecommons.org/licenses/by-nc/4.o/), which permits non-commercial re-use, distribution, and reproduction in any medium, provided the original work is properly cited. For citation use the DOI. For commercial re-use, please contact editor@rupkatha.com. 
plot is supplemented by "actual recipes" and "gumshoes not only track killers and determine motive but also grill sherry-flavoured tuna or bake batches of chewy "chocolate comfort cookies" (Carvajal, 1997, n.p.).So much so, that the sub-genre of crime fiction that brings together food and crime, has been termed as 'culinary mystery' (Baucekova,2015, 82) and with the more recent academic interest in food in literature, this genre has received the critical attention it deserves. Kevin Burton Smith, in his article in the Mystery Scene magazine, "Murder on the Menu", mentions that the connection between food and crime was "made in Rex Stout's Fer-deLance (1934), which introduced Nero Wolfe, the world's premiere foodie detective, whose entire life revolved largely around food and beer" (2010, n.p.). Many critics have, over the years, extensively written on the connections between crime and food. Nieves Pascual Soler in her $A$ Critical Study of Female Culinary Detective Stories: Murder by Cookbook (2009) explains the relationship between cooking and detection in contemporary culinary mysteries by interlinking the fields of crime and food. "Culinary Mysteries of the 1990's" by Daryll Anderson traces the growth and the development of this sub-genre of crime fiction attempts to understand the theme of feminism in culinary mysteries, which really are "exclusively cozies without a lot of violence" (2000, p.56). BeithKalikoff in her article "Killer Cupcakes: Food, Feminism, and Murder in Mystery Fiction by Women" analyzes these culinary mysteries which provide a space for women where their domestic skills like baking, cooking, serving are assumed as being valuable and that these skills "apply to the world beyond the kitchen, serving as analogues to and practice for the art of crime detection" (2006, p.74). Silvia Baucekova in her book Dining Room Detectives: Analysing Food in the Novels of Agatha Christie (2015) traces the history of food in literature and crime fiction in her introductory chapters and subsequently examines the role of food in Agatha Christie's mysteries. In Booze and the Private Eye: Alcohol in the Hard-Boiled Novel, Rita Elizabeth Rippletoe analyzes how food and alcohol add an element of credibility in crime narratives because food and cooking are part of everyday ritual, routine and convention and crime fiction "attempts to display the world as we know it, a world in which details matter" (2004, p.23).

The present paper will attempt to analyze the role of food in the mysteries of Madhumita Bhattacharyya, The Masala Murder (2012) and Dead in a Mumbai Minute(2014)and Kalpana Swaminathan's The Secret Gardener (2013) and Page 3 Murders(2006). The Madhumita Bhattacharyya novels provide an attractive corpus to examine how food is used as a detective's tool in solving overly complicated cases in the Reema Ray mysteries. On the other hand, Swaminathan's Lalli is shown to have a relish for food andher niece Sita enjoys indulging Lalli in these simple delights of life. In the process, the paper will also argue how these novels pose a challenge to the stereotypical roles of women being caregivers and providers of nutrition, and call into question the notion of the space of the kitchen being a female domain.

Food has been traditionally considered as having a close connection with domesticity, a realm that the woman is supposed to reign over. Lalli, Sita and Reema are however notable exceptions to this model of feminine care and domestic concern. These characters challenge this traditional idea of femininity, because none of them cooks to provide nourishment to a family or as a part of domestic responsibilities. Arlene Voski Avakian's anthology, Through the Kitchen Window: Women Writers Explore the Intimate Meanings of Food and Cooking, is a seminal work in addressing the varied and complex aspects of the relationships between women and food, and traces how cooking may have provided an outlet for women's creative expression. She feels that though food preparation, traditionally is a "part of invisible labour of women" (1997, p.6), however, women have often turned cooking into a "vehicle for artistic expression" as well as an opportunity for "resistance" (6). Reema Ray, Bhattacharyya's protagonist, is an independent woman, a trained private investigator and a part-time food-critic fora fashion magazine called 
Face. The only thing that enthuses her other than crime-solving, is food. At the very beginning of the novel, The Masala Murder, Reema transparently articulates her relationship with baking:

So when I found myself in a seemingly irredeemable slump, I baked. When I ran into trouble on a case, I baked. When I felt like nothing made sense, I baked. Baking, in fact, had seen me through a number of tight spots, so much so that I was forced to give away baked goods in order to reduce the strain on my waistline. (2)

Baking to Reema is not an imposition that needs to be engaged in because she has a household to provide for, rather food and cooking are seen here as symbols of independence, self-care and an assertion of individuality. Baking purges her mind of clutter, allowing Reema to understand incomprehensible scenarios. Even when Reema moves to a new city, in Dead in a Mumbai Minute, she searches ardently for a house with an oven, "the indispensable part of my kitchen arsenal" (2014, p.44). Reema is not just an unconventional professional, a private investigator but also a woman interested in cooking for all the "wrong reasons".

In The Secret Gardener, Sita uses cooking as a means to calm herself, "I needed some quiet myself and set about getting my usual fix of tranquilizer by starting the cooking” (86). Cooking as a therapeutic method to heal a stressed mind is a fact that has been constantly gaining ground. When she wants relief from the utter bewilderment that has overwhelmed her, she determinedly decides to concentrate on the "geometry of the chopping board" (86). She narrates that the menu will depend on her state of mind:

Anxiety demands the perfect brunoise, dice $1 / 8^{\text {th }}$ or $1 / 16^{\text {th }}$ of the inch depending on desperation. Sanity is medium dice. Exuberance is paysanne or mirepoix. Joy is julienne. Anger is a large dice and to hell with it. Most days I'm content with an easy macedoine or a quick chop, but today called for discipline. (2013, p.87)

Page 3 Murders starts with Lalli and Sita getting invited to a foodie weekend at Lalli's friend Hilla's seaside villa. The cook Tarok Ghosh serves more than just food on the night of the Millennial Banquet and over luscious cuisines, he spills some dark secrets that lead to his death later on. Tarok serves different dishes especially made for each guest on the Millennial Banquet night. For Hilla it was "a khakhra with a glistening red chunk of mango pickle" (2006, p.128) labelled "Sanjan 8 AD." (2006, p.128), for Dr. Sane, it was "Shorshemaach. Fish in mustard sauce, Siraj-ud-Daulah's kitchen, 1756" (2006, p.133),for Mr Bajaj it was "steak tartare" (2006, p.135), "a dish straight out of Changiz Khan's urt" (2006, p.135) and so on. While serving the delicacies, he simultaneously mentioned the history of the foods vis-a-vis disclosing the secrets the particular person shared with that particular dish. The pages that follow record a succulent menu of a mouth-watering grand dinner. And soon after the dinner is over he is murdered. The fag end of the novel shows Lalli exposing Mr Bajaj as the murderer. "The Mongols were the connoisseurs of horse flesh" (2006, p.135) was exactly what Tarok had said while serving the tartare to Mr Bajaj and Lalli explains:

'What did Tarok mean when he gave Mr Bajaj steak tartare?' Alif Bey asked. . . .Lalli smiled. 'That's what gave me the answer to the puzzle. Tarok made the distinction between horse flesh and human flesh. He was trying to tell Mr Bajaj he knew he was in the flesh trade.' (2006, p.280)

The solution to the murder mystery is encoded in the food served, and it is precisely because Lalliis able to decode it that she finds the murderer in a classic crime fiction closure. Carvajal writes that "recipes are no longer consigned to cookbooks; they are increasingly plot fixtures in a 
rapidly proliferating genre of culinary literature, including gourmet whodunits" and since the 1990s the fusion of actual recipes and writing has become as common as all-purpose flour -particularly in the odd category of mysteries." Food is more than just delectable description in Page 3 Murders. As we noticed earlier, it hides secrets which if read as clues can lead us to the criminal and the crime. Swaminathan intertwines food in an integral fashion with the main plot of this whodunit, where the female detective is adept at reading the clues left behind by the victim, because both understand "food".

In view of the cultural fixation on female slenderness and self-control, Reema Ray's eating habits or her attitude towards food can be seen as an expression of female independence and rebellion. In the book Blood on the Table: Essays on Food in International Crime Fiction, Hynymen in her article "Food and Gender in Crime Fiction", writes that "the cultural ideal of thinness imposed on women is a way of controlling and combating them in response to their growing presence and power in society" and with the growing liberation of women "society increasingly turned its attention from their actual abilities by keeping them preoccupied with their body, fashion and make-up" (2018, p.65). Reema Ray stands up against such an ideal and is represented as a woman who blatantly confesses that the only thing that excites her apart from detection is food. Hema Masi points out in The Masala Murder "She (Reema) has always loved food, and poking around in other people's business" (2012, p.170).In Dead in a Mumbai Minute, even when grave discussions on an investigation are going on, Reema cannot help but feel the pangs of hunger "food, I suddenly remembered" (2014,p.70) and later Shayak claims that the secret to Reema's happiness "Keeping you fed. At all times" (2014, p.5).

Food and poison have been intrinsically linked, as Franks et al. in their paper "Murder, They Cooked: The Role of Food in Crime Fiction" point out that "poison is a popular choice as a weapon within crime fiction" (2013, p.43). Food and poison play important roles in The Secret Gardener and The Masala Murder. Reema's world turns topsy-turvy when she gets the news of the death of Prakash Agarwal, the owner of Gourmet Express and a businessman who supplied gourmet provisions to the local restaurants. Although the death of Prakash Agarwal seemed an evident case of food poisoning, Reema's sharp investigative nose could sniff out a terrible mishap from the behaviour of the people associated with the dead. Finally Reema discovers that Vineeta, who had faced prolonged sexual exploitation at Prakash's hands, had put "ricin" (2013, p.264) into Prakash's snuff bullet. In The Masala Murder, we again see that food is not an empty signifier, but becomes the medium of murder as well as the method of detection. In The Secret Gardener, there are two cases of poisoning, Sukesh, the prime witness to the murders of Varsha's parents, dies of swallowing insecticide "mixed in chicken biryani" (2013, p.47) and the murder of Rita, the woman with whom Varsha's husband had an affair with, who dies of eating kheer mixed with poison. The poison that was used for murdering Rita was "cyanide" (2013, p.238) which according to Franks et al. is "another classic poison" (2013, p.43). The cyanide had been mixed in a bowl of kheer, which is usually served as a dessert, at the end of a meal. Before the resolution is reached, Lalli asks Sita to make desserts for everyone. Even when everyone is waiting for Lalli to reconstruct the events that happened on the night of Rita'a murder, Lalli insists on having the dessert, "zabaglione" (2013, p.201) served; consequently revealing that it was in fact the dessert that had been the medium of administering the poison, "I asked Sita to make this dish because it's exactly like the story I have to tell tonight" (2013, p.206). Silvia Baucekova asserts that a detective story should be like a recipe, following a set of certain rules in certain order and by using specific ingredients(2015, p.85) and cites Cawelti: 
Another parallel between mystery and a recipe is that in a detective story, murder is not understood as sinful, immoral, violent, and horrible, but is instead, like a tasty dish, seen as a way to pleasure. And like food, a mystery brings its readers not only pleasure, but also suspense as they wait for the solution to be prepared and revealed, feeling first the anticipation and then the gratification when the finished product is presented and their curiosity sated. (2015, p.85)

Crime fiction is also genre fiction, depending upon well tested conventions and formulae, and here, the Lalli mystery novel is like a recipe that has definite measures of ingredients added at the right time and draws a perfect closure by serving a delectable and sumptuous dessert.

The relationship Reema shares with food and baking has already been discussed earlier. In the novel, the final breakthrough comes when one night, Reema decides to bake puff pastry. Every time Reema is overwhelmed by clues and information in a case, she decides to pull off a puff pastry, a dish that requires a lot of effort and patience "I rolled and folded, folded and rolled. As my pastry began to take shape, ideas came together in my head. . And then I put the dough in the freezer. . .Then another round of rolling, as I ignored the ache in my arms' (2012, p.215). Going through the elaborate motions of baking the pastry, she processes available information about the case, and arrives at a solution. The murder was committed over spices. In Dead in a Mumbai Minute, epiphany dawns on Reema while making a bowl of salad "Clarity had arrived, as usual, all at once, cutting through the fog of memory and meaning"(2014, p.270).

Thus, food in these contemporary Indian English detective novels goes much beyond its ornamental functions. Both Lalli and Reema are professional detectives who draw on their feminine intuition and their knowledge of food and cooking methods. But they are far removed from the traditional domains of domesticity and caregiving. Unapologetically single, Lalli, Sita and Reema connect to food as an indulgence after a hard day's work or a tool for detection. In The Secret Gardener, Lalli and Sita, in an age of junk-food, go back to the wholesome nutrition of homemade healthy food. The food nourishes their body and mind, making them more astute sleuths. Bhattacharyya's detective is independent Indian woman, who leads her life absolutely on her terms and she hones her investigative expertise through cooking. These female detectives are a part of a long global tradition of women investigators created by women crime writers, independent, confident and clever women who solve crimes from their knowledge of human behaviour and of the domestic milieu. Beith Kalikoff in her article "Killer Cupcakes: Food, Feminism, and Murderin Mystery Fiction by Women" rightly points out the reasons behind the popularity of culinary mysteries and how food plays a part in empowering women:

Food mysteries are ultimately about female independence and sustaining the self. Moreover, the writers of food mysteries have - with some energy, wit, and originality shown the same independence as their protagonists. By creating new food subgenres, they have reclaimed and combined soft-boiled (Christie) and hard-boiled (Hammett) mystery series.. (2006, 74-75)

\section{References}

Albala, K. (2013). Routledge International Handbook of Food Studies. London:Routledge.

Anderson, D. (2000). Culinary Mysteries of the 1990's. Studies in PopularCulture, 23(2), 55

63.RetrievedAugust 15, 2020, fromwww.jstor.org/stable/23414544. 
Avakian, A.V. (1997). Through the Kitchen Window: Women Writers Explore the Intimate Meanings of Foodand Cooking. Boston: Beacon Press.

Baucekova, S. (2015). Dining Room Detectives: Analysing Food in the Novels of AgathaChristie. UK: Cambridge Scholars.

Bhattacharyya, M. (2012). The Masala Murder. New Delhi: Replika Press.

Bhattacharyya, M. (2014). Dead in a Mumbai Minute. New Delhi: Replika Press.

Hynynen, A. (2018). Food and Gender in Crime Fiction: Attitudes to Food and Eating among Female Detectives. In J. Anderson, C. Miranda, B. Pezzotti (eds.), Blood on the Table: Essays on Food in International Crime Fiction (pp. 63-75). North Carolina: McFarland Et Company, Inc., Publishers.

Smith, K.B. (2010, n.d.) Murder on the Menu. The Mystery Scene 116(4). Retrieved from https://www.mysteryscenemag.com/article/2754-murder-on-the-menu

Cawelti, John G. (1976). Adventure, Mystery, and Romance: Formula Stories as Art andPopular Culture. Chicago: University of Chicago Press.

Carvajal, Doreen. (1997, November 16). Be Thankful This Isn't a Story about Cannibalism. Retrieved from https://www.nytimes.com/1997/11/16/weekinreview/be-thankful this-isn-t-a-story-about cannibalism.html.

Franks, R., Brian, D. L., and Usiekniewicz, M. (2013, June, 24-26). Murder They Cooked: The Role of Food in Crime Fiction. Peer Reviewed Proceedings of the $4^{\text {th }}$ Annual Conference, Popular Culture Association of Australia and New Zealand(POPCAANZ), Brisbane, Australia.

Kalikoff, B. (2006). Killer Cupcakes: Food, Feminism, and Murder in Mystery Fiction by Women. CEA Critic, 69(1/2), 67-76. Retrieved August 16, 2020, from www.jstor.org/stable/44377636.

Soler, N.P. (2009). A Critical Study of Female Culinary Detective Stories: Murder byCookbook. Lewiston: The Edwin Mellen Press.

Rippetoe, Rita Elizabeth. (2004). Booze and the Private Eye: Alcohol in the Hard-BoiledNovel. North Carolina:McFarland\& Co.

Swaminathan, K.(2007). The Page 3 Murders. New Delhi: IndiaInk.

Swaminathan, K. (2013). The Secret Gardener. New Delhi: Penguin Books.

Somjeeta Pandey is currently working as an Assistant Professor of English at a government-aided college in West Bengal, India. She is also a part-time PhD research scholar at the Department of Humanities and Social Sciences at Indian Institute of Technology, Kharagpur.

Dr Somdatta Bhattacharya is currently an Assistant Professor at the Department of Humanities and Social Sciences, IIT Kharagpur, West Bengal, India. She has previously taught at the University of Hyderabad (2011-2013) and at BITS Pilani (2013-2018). Her research interests are rooted in areas such as city in literature, social theories of space and spatiality, crime fiction, urban cultural studies, and South Asian popular culture. She is currently engaged in two projects examining the relationship between migrant female urban labourers and the city space, one funded by ICSSR and another by IIT Kharagpur. 